\title{
KECAKAPAN HIDUP DARI PEMBELAJARAN PANDEMI COVID -19 (STUDI DDESKRIPTIF DAN SURVEI DI SMA NEGERI 67 JAKARTA)
}

\section{Sarwiyoto}

How to cite : Sarwiyoto, 2021. KECAKAPAN HIDUP DARI PEMBELAJARAN PANDEMI COVID -19 (STUDI DDESKRIPTIF DAN SURVEI DI SMA NEGERI 67 JAKARTA). Jurnal Penelitian dan Penilaian Pendidikan. 3(2). 121 - 137.

To link to this article : https://doi.org/10.22236/jppp.v3i1.5913

(C2021. The Author(s). This open access article is distributed under a Creative Commons Attribution (CC BY-SA) 4.0 license.

\section{Published Online on 30 July 2021}

转 https://journal.uhamka.ac.id/index.php/jppp

View Crossmark data 4 


\title{
KECAKAPAN HIDUP DARI PEMBELAJARAN PANDEMI COVID -19 (STUDI DDESKRIPTIF DAN SURVEI DI SMA NEGERI 67 JAKARTA)
}

\author{
Sarwiyoto $^{\mathbb{\square}}$ \\ ${ }^{1}$ Universitas Muhammadiyah Prof DR HAMKA \\ E-mail: $\quad$ sarwiyoto@gmail.com ${ }^{l)}$
}

Received : 2 April 2021

Accepted: 25 July 2021

Published Online: 30 July 2021

\begin{abstract}
Abstrak
Masalah wabah yang dikenal dengan sebutan covid-19 telah berdampak pada bidang kesehatan, bidang ekonomi, budaya dan dunia pendidikan. Agar tidak meluas penyebarannya, pemerintah menganjurkan agar melaksanakan 'social distancing' dan 'lockdown'. Dibidang pendidikan, kementrian dan jajarannya telah mengeluarkan regulasi yang mengatur proses pembelajaran. Sejak pandemi covid-19 diumumkan, penulis melakukan penelitian terhadap peserta didik yang diampu selama pembelajaran tentang media daring, kesiapan peserta didik dan kecakapan hidup yang diperoleh. Hasilnya menunjukkan 93,9\% peserta didik hadir, 95,4\% pembelajaran dengan media google classroom dan kemampuan dalam menyelesaikan tugas 6,1\% sangat mampu, 59,5\% mampu, dan 32,6\% cukup mampu. Hasil survei juga menunjukkan tidak semua peserta didik dapat mengakses internet sebagai sarana program pembelajaran jarak jauh. Disarankan kepada lembaga yang berwenang untuk memberikan solusi agar semua peserta didik dapat mengakases internet sebagai sarana dalam program pembelajaran jarak jauh. Sebagai guru hendaknya selalu mengembangkan dan meningkatkan kompetensinya agar dapat menyesuaikan dengan abad revolusi industri 4.0. dalam posisi ditengah-tengah peserta didik.
\end{abstract}

Kata kunci: Google Classroom, Kecakapan Hidup, Pandemi Covid-19, dan PJJ.

\begin{abstract}
The epidemic problem known as Covid-19 has had an impact on the health sector, the economy, culture and the world of education. In order not to spread the virus, the government recommends implementing 'social distancing' and 'lockdown'. In the field of education, ministries and staff have issued regulations governing the learning process. Since the Covid-19 pandemic was announced, the authors conducted research on students who were assisted during learning about online media, student readiness and life skills acquired. The results show that $93.9 \%$ of students attend, $95.4 \%$ learn with Google Classroom media and the ability to complete assignments $6.1 \%$ are very capable, 59.5\% are able, and $32.6 \%$ are quite capable. The survey results also show that not all students can access the internet as a means of distance learning programs. It is suggested to the authorized institution to provide a solution so that all students can access the internet as a tool in distance learning programs. As a teacher, you should always develop and improve your competence so that you can adapt to the industrial revolution 4.0. in the middle of the students.
\end{abstract}

Keywords: Covid-19 Pandemic, Google Classroom, PJJ, and Life Skills.

This is an open access article under the Creative Commons Attribution 4.0 International License 
Sarwiyoto

1. PENDAHULUAN

Menghadapi situasi yang melanda Indonesia akibat adanya penyebaran Virus Corona, diperlukan suatu sikap hidup yang dapat mengatasi timbulnya suatu keresahan. Jutaan orang terinfeksi diseluruh dunia, ratusan ribu orang wafat, serta ratusan ribu yang lain hadapi penyakit parah. Pandemi covid-19 berefek kepada masalah kesehatan, baik fisik maupun mental. Kesehatan fisik dapat dilihat dari kondisi tubuh yang bugar, sedangkan kesehatan mental dapat dirasakann dari adanya keresahan dan kekhawatiran seseorang akan terjangkitnya virus atau dirinya terinfeksi. Demikian juga kekhawatiran terhadap orang-orang terdekat atau saudaranya yang berada dikejauhan.

Masalah wabah covid-19 disamping berdampak pada bidang kesehatan namun juga berdampak pada sisi kehidupan lain seperti ekonomi, budaya dan hubungan sosial masyarakat. Selain itu juga permasalahan dalam dunia pendidikan. Dunia pendidikanpun memerlukan penanganan yang serius, karena menyangkut kehidupan psikhologis anak akan masa depan. Harapan masyarakat dalam situasi seperti ini adalah bagaimana terlayaninya kebutuhan pendidikan yang sesuai capaian tujuan pendidikan.

Istilah Covid-19, oleh World Healt Organization (WHO) sebagai virus jenis baruyang berasal dari pasar ikan Huanan di Wuhan Provinsi Hubei, Tiongkok. Awal bulan Desember 2019, menurut mendiang Dr. Li Wenliang banyak berdatangan pasien kerumah sakit di Wuhan, pernah memberikan informasi dibeberapa media sosial, bahwa para pasien tersebut terkena penyakit yang menyerang radang paru-paru dan diduga diakibatkan oleh virus jenis baru yang kemudian ditetapkan oleh WHO.

Wabah atau pandemi yang disebabkan oleh coronavirus disease (COVID-19) sebenarnya disebabkan oleh virus jenis baru SARS-CoV-2. Pandemi COVID-19 muncul pertama kalinya dideteksi di Kota Wuhan, Provinsi Hubei, Tiongkok pada Desember 2019. Dan ditetapkan sebagai pandemi oleh Organisasi Kesehatan Dunia (WHO) pada 11 Maret 2020. Hingga 28 Maret, lebih dari 620.000 kasus COVID-19 telah dilaporkan di lebih dari 190 negara dan teritori, mengakibatkan lebih dari 28.800 kematian dan 137.000kesembuhan.

Tidak terkecuali Indonesia dengan adanya kasus tersebut diatas maka dengan berbagai kebijakan berupaya agar masyarakat tidak tertular atau terpapar covid-19 dimasa pandemic covid ini, dengan melakukan sosialisasi terhadap maasyarakat baik dikota kotabesar maupun didaerah. Mengacu pada Keputusan Presiden Nomor 7 Tahun 2020 tentangGugus Tugas Percepatan Penanganan pandemic Covid-19, berupaya agar masyarakat memiliki ketahanan nasional dibidang kesehatan, dan mempercepat penanganan wabah Covid-19 melalui Kerjasama antar kementrian atau isntansi lain agar sinergi dalam menangani permasalahan yang berhubungan dengan Kesehatan khususnya pandemic covid 19.

Menyikapi pandemi covid-19 upaya Kementrian Pendidikan langkahnya adalah, mengeluarkan surat edaran mentri Pendidikan nomor 3 tahun 2020, yang kalau penulis analisis, esensinya adalah tidak memperbolehkan sikap kepanikan, dan kemudian berwaspada, serta memahami edukasi tentang pandemic covid-19 baik jenis 
Kecakapan Hidup dari Pembelajaran Pandemi Covid-19...

virusnya, ciri-cirinya dari informasi yang kita dapat sampai dengan bagaimana caranya melakukan pencegahan dan penanganan pandemic. Sedangkan fihak dinas Pendidikan sebagai kepanjangan kementrian, menerbitkan edaran pada Surat bernomer: 16/SE/2020 untuk menyikapi perkembangan kasus pandemic Covid-19. Surat tersebut menghimbau seluruh jajaran Dinas Pendidikan memberikan informasi tentang kajian dan upaya dalam melakukan pencegahan serta penularan pada saat pandemic covid-19. Kepada seluruh jajarannya yang merupakan bagian dalam sistem pendidikan baik formal non formal untuk tetap melaksanakan regulasi yang telah diterbitkan. Di dalam himbauannya kepala dinas menyampaikann agar semua komunitas dilingkungan pendidikan melaukan banyak berdo'a, agar selalu sehat dan wabah ini segera berakhir, sehingga akan Kembali dalam kehidupan yang normal. Mengonsumsi makanan sehat dan berimbang, melakukan kegiatan yang sifatnya dapat menyehatkan badan agar selalu tetap bugar dalam kesehariannya. Menghindari kegiatan di keramaian yang tidak ada maslahatnya, juga membatasi kegiatan-kegiatan yang menimbulkan kerumunan, hal ini agar dihindarisebagai bentuk upaya menjaga Kesehatan.

Memperhatikan berbagai kebijakan jajaran pemerintah dalam mengantisipasi pandemi Covid-19 dan tetap berjalannya aktivitas pemerintahan dalam layanan terhadap masyarakat, serta agar tetap tercapainya sasaran kinerja pemerintah dalam memenuhi kebutuhan hidup baik sektor riil maupun jasa, maka penulis tertarik untuk mengambil Langkah konkrit dalam tugasnya sebagai seorang guru untuk mencari solusi dan analisisnya selama pandemi covid-19 yang dituangkan dalam bentuk karya tulis dengan harapan dapat menemukan solusinya agar kinerjanya tetap semangat dan proses pembelajarannya tetap berjalan dengan semestinya. Maka dalam kegiatan penulisan ini penulis mengambil judul: "Kecakapan hidup dari pembelajaran pandemi covid -19".

Dari latar yang telah penulis uraikan diatas, maka penulis dapat mengidentifikasikan masalahnya sebagai berikut:

1) Pandemi Corona atau Covid-19 pada masyarakat mengancam jiwa manusia.

2) Metode yang tepat dan efektif ditengah pandemi Covid-19 sebagai upaya layanan pembelajaran terhadap peserta didik.

3) Apasajakah kecakapan hidup yang diperoleh dalam pembelajaran berkaitan dengan pandemic covid 19 ?

Sesuai dengan rumusan masalah yang telah penulis utarakan di atas, tujuan penulisan adalah :

1) Mendapatkan pengetahuan dan memahami pandemi Corona atau Covid-19 pada masyarakat yang mengancam jiwa manusia.

2) Mengetahui dan menganalisis proses pembelajaran jarak jauh dengan metode yang tepat dan efektif.

3) Mengetahui kecakapan hidup yang diperoleh peserta didik pada saat pandemi covid-19 melalui pembelajaran jarak jauh. 
Harapan penulis, hasil tulisan memiliki beberapa manfaat antara lain:

Sebagai bahan kajian dalam metode pembelajaran jarak jauh ataupun pembelajaran lain yang menggunakan model pembelajaran yang efektif. Tulisan ini dapat dijadikan sebagai rujukan dalam menggali ide-ide yang muncul saat menghadapi permasalahan diluar kebiasaan, sebagai contoh pandemi covid-19.

\section{KAJIAN TEORI}

\section{Pandemi Corona (Covid-19)}

Wabah virus covid-19 telah meluas ke penjuru dunia, oleh World Healt Organization atau WHO ditetapkan sebagai sebagai pandemi, suatu wabah yang terkenamusibah serupa diberbagai daerah, meliputi wilayah geografi yang luas, tidak terkcuali Indonesia. Sampai sekarang, sudah 118 negeri memberi informasi permasalahan mengenai wabah virus corona. Selanjutnya, pada pusat pengendalian penyakit menyebutkan bahwa pandemi akan menyebar diberbagai wilayah yang akan berpengaruh terhadap banyak manusia. Dengan kata lain, pandemi ditetapkan jika gelombang infeksi terjadi dari orang ke orang, dan terjadi pada seluruh komunitas.

Setelah pandemi diumumkan, pemerintah dengan segala aparaturnya melakukan berbagai upaya dalam menangkal perkembangan pandemic ini yang semuanya diharapkan akan dapat memastikan kesiapan untuk menanganinya. Dalam mengalamipandemi yang mendunia, secara universal terdapat 3 tata cara utama buat menanggulangi pandemi ialah mengasingkan diri ataupun memisahkann diri dari komunitas, diadakan uji massal serta kekebalan tubuh terhadap virus. Kewenangan pemerintah resmilah yang melaksanakan secara bertepatan, dengan mengutakanan salah satunya. Sedangakan metode terakhir, pada umumnya sangat lambat serta berdampak pada banyaknya korbanmanusia.

Jika kita perhatikan di negeri Tiongkok tempat asal Covid- 19, mereka sukses dengan mengutamakan metode yang awal. Isolasi, karantina ataupun tata cara mengekang masyarakat untuk tidak keluar rumah hal ini merupakan Tindakan yang kurang terpuji. Sebaliknya disalah satu negara yang melaksanakan uji massal tentang Covid- 19. Dapatdiibaratkan semacam penyaringan, terus menjadi luas penyaringnya hingga terus menjadibanyak ditemukan. Sehingga, sebaran wabah atau pandemi dapat diantisipasi dengan lebih kilat.

Pemecahan yang terbaik buat negeri Indonesia merupakan dengan role model sebab negeri kita bagaikan negeri kepulauan serta penduduk yang multi komplek dalam penindakan Covid- 19 yang sangat cocok. Mempraktikkan usaha-usaha penangkalan secara tegas, dan tidak hanya himbauan. Mengangani permasalahan pandemic ini pihak pemerintah bisa menghasilkan biaya besar buat pengadaan uji covid, masker, dan biaya lain yang berkaitan dengan kesehatan untuk kesehatan masyarakat. Proses pencegahan secara massal pada lokasi yang sering dikunjungi masyarakat, serta pengadaan seluruh perlengkapan materi yang diperlukan tenaga kedokteran buat menanggulangi penderita pasien yang telah terkonfirmasi positif. 
Kecakapan Hidup dari Pembelajaran Pandemi Covid-19...

Disamping pemberlakuan isolasi terhadap area yang membahayakan bagi masyarakat.

Oleh karena itu setiap anggota masyarakat dalam kondisi seperti sekarang ini sangat dibutuhkan kualitas hidupnya yang memadai agar tidak terkena pandemi-19. Kualitas hidup disini diartikan sebagai bagian dari tubuh yang sehat, namun ada halhal yang dirasakannya, sebagaimana perasaan masyarakat tersebut dapat terjaga perasaannnya untuk senantiasa meningkatkan daya imunitasnya. Dalam pembangunan manusia, istilah kualitas hidup kita jumpai pada masyarakat yang tidak pernah terkena penyakit. Karena istilah mutu hidup bagai seseorang dapat diperoleh dari bagaiana setiap orang berinteraksi dengan faktor lain yang berpengaruh pada kondisi tubuh seseorang yang dihubungkan dengan kondisi sosial, kondisi ekonomi dan kondisi lingkungan.

\section{Virus Corona (Covid-19)}

Dimasa pandemi seperti sekarang, kita menjadi tahu akan adanya virus yang namanya covid, kepanjangan dari corona diseserse berasal dari bahasa latin, jika diperhatikan dengan sebuah alat pembesar akan nampak seperti mahkota. Menurut para ahli virus corona dikenal sekitar tahun 1937 yang dapat mengakibatkan penyakit bronchitis dan menular yang berasal yang virus corona pada tahun 1937 dan menyebabkan penyakit bronkitis menular pada unggas.

Sekitar tahun 1965, ada dua peneliti yang bernama Tyrrell dan Bynoe, keduanyamenyimpulkan dari hasil temuannya bahwa virus corona pada diri sesorang yang sedangmengidap flu, diketahui dari kultur organ trakea embrionik dalam saluran pernapasan seseorang Ketika sedang flu. Selanjutnya pada akhir 1960-an, keduanya melakukan penelitian kembali terhadap strain virus pada manusia dan hewan. Hal ini meneliti dan vokus pada tiga jenis virus, yaitu virus infeksi bronkitis, virus hepatitis tikus dan virus gastroenteritis babi ketiga jenis virus tersebut dapat ditularkan, dan ditunjukkan secara morfologis hingaa dapat dilihat melalui alat mikroskop.

Wabah virus yang melanda saat ini, untuk pertama kalinya muncul lalu menyebar ketubuh manusia berasal dari China diprovinsi Wuhan sekitar akhir Desember 2019. Kemudian wabah ini dicari sumber asalnya, dan ternyata dari beberapa orang yang terinfeksi mereka pernah berkunjung ke suatu pasar yang menyediakan makanan laut dan hewan yang hidup di Wuhan. Diberitakan dalam majalah The New York Times, bahwa pasar tersebut kemudian ditutup dan didesinfeksi, kemudian suatu hal yang mustahil akanada penelitian untuk menyelidiki bahwa hewan mana yang diduga sebagai asal mula dari penyakit dan kemudian menjadi wabah. Namun disisi lain peneliti menganggap hewan kelelawarlah yang dianggap sebagai sumber wabah yang berevolusi untuk hidup berdampingan dengan virus-virus lainnya. Selanjutnya, virus corona yang menjadi sumber wabah ini dikenal dengan istilah COVID-19 memicu wabah di wilayah Cina danberkembang di berbagai belahan dunia sehingga WHO mendeklarasikannya sebagai pandemi global. 
Sarwiyoto

Coronavirus Disease 2019 adalah jenis baru sumber wabah yang kemudian dikenal dengan sebutan COVID-19. Virus tersebut yang akan mengganggu pernapasan pada seseorang dan juga bisa menimbulkan radang pada peru-paru. Diduga oleh para ahli bahwa penyakit tersebut menjadi infeksi Severe Acute Respiratory Syndrome Coronavirus 2 (SARS-CoV-2). Berbagai tanda-tanda seseorang terinfeksi virus, antara lain seperti gejala flu biasa (batuk-batuk, disertai pilek, nyeri pada tenggorokan, nyeri pda otot, nyeri dikepala) hingga yang berkomplikasi berat (sepsis atau pneumonia).

\section{Proses penularan COVID-19}

Penyakit baru yang dikenal dengan istilah COVID-19 sampai dengan sekarang para ahli dan dokter melakukan penelitian dan mempelajari bagaimana proses penularan terhadapmanusia yang lain. Berbagai analisis dari hasil penelitian, mereka menduga bahwa metode penyebarannya adalah melalui droplet pada saluran pernapasan sipenderita kemudian mereka mengadakan kontak yang tidak berjarak dengan penderita tanpa menggunakan masker. Apakah yang dimaksud dengan droplet yaitu suatu partikel yang sangat kecil berasal dari dalam mulut sipenderita yang mengandung virus, pada saat batuk, atau saat berbicara serta bersin. Droplet tersebut sampai kepada manusia yang lain yang berada disekitarnya atau yang diajak kontak dalam radius satu meter.

Dari sipenderita droplet dapat hinggap pada pakaian atau benda disekitarnya pada saat bersin atau batuk yang mengeluarkan cairan ataupun lendir. Selanjutnya partikel droplet tersebut Ketika menempel pada benda lain sebenarnya tidak akan dapat bertahan lama begitu juga jika mengendap di udara juga tidak akan bertahan dalam jangka waktu yang lama. Oleh karena itu, untuk menghindari dari penyebaran virus tersebut, masyarakat diwajibkan untuk menggunakan masker yang higienis atau masker kain yangcukup tebal (kain berlapis tiga) sehingga dapat menutupi hidung dan mulut dari penyebaran virus covid-19 yang terdapat dalam droplet seseorang yang terkena penyakit.

\section{Infographic-covid19-gejala-dan-komplikasi}

Sebenarnya, ketika sipenderita terkena covid-19 adalah bahwa penderita bergejala sepertiflu biasa sampai pada kondisi yang sangat berat seperti pneumonia atau radang pada paru yang gejalanya sesak napas dan tersengal-sengal. Oleh karena itu, jika sudahmengalami gejala seperti diataas, atau mempunyai historis perjalanan dari suatu wilayah yang terkena penyakit atau pandemi, atau kontak dengan orang positif atau orang tanpa gejala covid-19, maka sebaiknya orang tersebut melakukan isolasi mandiri agar tidak menyebar ke oaring lain.

\section{Pembelajaran Jarak Jauh}

Dalam menghadapi situasi pandemi covid-19, pemerintah melalui kementrian pendidikan mengeluarkan Surat Edaran Nomor 3 Tahun 2020 tertanggal 9 Maret 2020 berkaitan dengan pencegahan penyebaran Corona Virus Disease atau covid-19 dalam satuan Pendidikan baik pendidikan dasar maupun menengah dan dimana surat 
Kecakapan Hidup dari Pembelajaran Pandemi Covid-19...

tersebut berisi tentang protokol dalam rangka usaha pencegahan perkembangan dan penyebaran Corona Virus di lingkungan satuan Pendidikan serta pelayanan pada masyarakat selama terjadinya pandemi covid-19.

Surat edaran tersebut kemudian disikapi oleh fihak terkait Provinsi Daerah Khusus Jakarta dengan mengeluarkan regulasi yang berkaitan dengan SE Mendikbud Nomor 3 tahun 2020, mengenai tindakan preventif pada pencegahan dan mengurangi risiko penularan infeksi covid-19 atau Corona Virus. Salah satunya mengeluarkan Edaran bernomor 27/SE/2020 tentang pembelajaran dari rumah (Home Learning). Selain mengeluarkan kebijakan tersebut, Dinas Pendidikan juga memberikan arahan tentang pelaksanaan pembelajaran di sekolah. melalui pembelajaran sistem daring. Mekanisme dalam pembelajaran dari rumah atau daring sarana yang digunakan adalah computer, dawai dengan internet ini hal ini dapat diterapkan dan dikembangkan pada saatpandemi covid-19.

Pembelajaran jarak jauh atau yang juga diistilahkan dengan (distance education) merupakan sistem pendidikan formal dimana para siswa dengan gurunya berbeda tempat belajar dan mengajarnya dengan menggukan sarana telekomunikasi sebagai sarana agar keduanya interaktif dalam proses belajar mengajar dalam rangka mencapai tujuan pendidikan. Hal ini dapat pula dilihat pada pengertian pembelajaran jarak jauh.

Proses belajar jarak jauh dengan mengguakan sarana internet adalah suatu kegiatan yang dilakukan untuk mengatasi persoalan pembelajaran pada saat pandemic covid-19 yang melanda negara Indonesia. Dengan adanya pembelajaran ini, guru dengan peserta didiknya berupaya menggunakan bermacam-macam media pembelajaran. Pembelajaran daring (online) merupakan pembelajaran dengan menyatukan pengetahuan bidang teknik elektro dan pengetahuan bidang teknik berdasar pada pemanfaatan internet.Saat ini, dunia pendidikan sangat dipengaruhi oleh teknologi komunikasi dan informasi, hal ini dapat membuat seseoarang untuk dapat mengembangkan kreativitasnya untuk dapat menyampaikan aspirasinya dalam pembelajaran dengan menggunakan berbagai aplikasi yang terdapat dalam kontenkonten pilihan yang disajikan oleh dinas pendidikan. Metode pembelajaran yang berkembanga saat ini terasa begitu cepat karena sistem pembelajarannya yang sudah tidak lagi dibatasi oleh waktu, tempat atau ruang belajar.

Adanya kemajuan teknologi dan beragam inovasi media digital maka seorang guru sebagai garda terdepan dalam pendidikan mampu menyesuaikan akan perkembangan teknologi agar tidak kalah dengan peserta didiknya. Pada unit pelaksana, seorang guru dituntut untuk dapat menyesuaikan dan mengikuti perkembangan teknologi sesuai dengan kompetensinya sehingga dapat melaksanakan tugas pokok seorang guru sekaligus kewajibannya secara ikhlas tanpa adanya kendala yang dihadapi saat menggunakan teknologi informasi dalam pembelajaran hingga para siswa tetap mendapatkan pengetahuan dan keterampilan seperti yang tersirat dalam amanat Undang-undang Pendidikan Nasional. 
Sarwiyoto

Pendidikan jarak jauh dapat dikatakan sebagai suatu pembelajaran yang akan selalu dinamis bersamaan dengan berkembangnya kemajuan informatika dan teknologi yang berkaitan dengan penggunaan internet. Oleh sebab itu, menurut penulis, yang dikatakan pembelajaran daring dapat dikatakan sebagai sistem pendidikan dengan menerapkan berbagai inovasi dalam metode pembelajaran, dan pembelajaran ini memiliki daya jangkau yangluas karena tidak terbatas oleh ruang, waktu, dan sosial ekonomi. Adanya perubahan system pembelajaran yang dikaranakan pandemic covid-19, maka diperlukan system pembelajran untuk menghindari covid tersebut dengan cara tersebut diatas. Terkait Pendidikan Jarak Jauh memiliki prinsip-prinsip yang mencakup sebagai berikut:

Berdasar pada pemanfaatan teknologi informasi dan komunikasi, untuk digunakan secara menyeluruh, dan terjangkau oleh segenap lapisan masyarakat dan tidak terkendala oleh jarak dan waktu. Didasrkan pada nilai-nilai adil dan hak yang sama bagi setiap peserta didik atau siapa saja untuk mendapatkan layanan pendidikan untuk mencapai sasaran pendidikan. Dalam pembelajarannya bersifat interaktif dan berdasar pada teknologi informasi dan komunikasi dari penyampaian tujuan pembelajran sampai dengan evaluasi pembelajran. Dalam pendidikan jarak jauh terdapat beberapa indikator sebagai berikut: saat proses pembelajaran berlangsung, guru dan siswa berada ditempat yang berbeda; materi ajar yang disampaikan, menggunakan perangkat yang didukung internet; sistem pembelajarannya dengan mengikuti sintak yang dipandu oleh guru atau lembaga pendidikan; pada setiap pertemuan atau tatap muka ditentukan dengan jadwal pembelajaran; ditinjau dari segi waktu, pembelajarannya bersifat fleksibilitas karena baik guru maupun siswa dapat memilih waktu yang dipandang tepat.

\section{Pembelajaran Daring dan Jenis Layanannya}

Adanya kebijakan institusi dari Dinas Pendidikan terkait, akibat pandemi covid- 19, maka satuan pendidikan segera mempersiapkan segala sesuatunya yang berkatitan dengan pembelajaran daring. Sistem dalam pembelajaran daring tentunya meliputi tenaga kependidikan, sarana penunjang, materi ajar, jadwal kegiatan pembelajaran dan programpembelajaran jarak jauh.

Program pembelajaran daring dapat dilakukan secara optimal dan efektif apabila antara pendidik dengan peserta didik dapat berkomunikasi secara intensif tanpa adanya kendala yang membuat pembelajran menjadi tidak bermakna. Pembelajaran bermakna menjadi tujuan dalam proses kegiatan belajar mengajar agar tujuannya tercapai. Layanan dalam pembelajaran jarak jauh terdapat beberapa jenis konten pilihan dalam pembelajaran diantaranya dengan google classroom.

Pengertian google classroom dalam bahasa Indonesia dapat diartikan sebagai ruang kelas google. Kelas google digunakan sebagai blok atau ruang pembelajaran dengan system e-learning. Aplikasi google classroom merupakan layanan berbasis internet yang dimiliki google. (Abdul Barir Hakim: 2016:2). 
Kecakapan Hidup dari Pembelajaran Pandemi Covid-19...

Aplikasi google classroom terdapat bermacam-macam sarana yang dapat digunakan oleh setiap orang dalam lingkup pendidikan. Sarana yang dimaksud adalah layanan dalam pembelajaran seperti menyusun, membagi, mengirim pesan dan mengklasifikasikan setiap jenis tugas yang dikirim kepada siswa tanpa menggunakan kertas. Google classroom merupakan salah satu aplikasi pembelajaran jarak jauh terkait adanya kewajiban belajar dari rumah. Pembelajaran model ini dimaksudkan agar pesertadidik terhindar dari penyebaran virus yang saat ini sangat membahayakan bagi keselamatan jiwa seseorang. Keselamatan jiwa seseorang lebih diutamakan sedangkan untuk mendapatkan pengetahuan dapat diupayakan dengan aktivitas literasi lainnya.

Aplikasi google classroom memudahkan guru dalam mengatur sistem aktivitas dalam belajarnya. Seorang guru dapat menjadwalkan bentuk aktivitas peserta didik dengan memperhatikan pada rencana pembelajaran yang telah disusunnya. Misalnya saja pada pekan pertama kegiatannya adalah pembahasan materi-materi esensial denganmemaparkan presentasi power point. Pada pekan kedua aktivitasnya pembentukan kelompok untuk selanjutnya mendiskusikan materi-materi berkaitan dengan materi pada pekan pertama, selanjutnya hasil diskusinya dapat dikumpulkan melalui e-mail. Pada pekan ketiga guru menindaklanjuti hasil diskusi kelompok untuk dibagikan kepada siswa dan selanjutnya peserta didik merespon dan mereviu pesan-pesan yang disampaikan oleh gurunya berkaitan dengan hasil tugas kelompoknya. Pada pekan keempat atau minggu terakhir guru dapat menentukan kegiatannya dengan mengadakan penilaian harian.

Dengan menggunakan konten aplikasi google classroom memungkinkan proses belajar mengajar menjadi lebih efektif dari segi waktu dan lebih menghasilkan serta sangat bermakna dalam menyusun tugas lebih disederhanakan, meningkatkan motivasi peserta didik dalam bekerja sama, dan membangun komunikasi. Guru dapat memanaj antara lain menyusun kelas, menugaskan siswa, mengirim tugas, memberikan saran, berbagi informasi, memberi pertanyaan, dan materi atau bahan ajar serta memperhatikan proses pembelajaran disatu tempat. Aplikasi google classroom memberikan kemudahan alur hubungan antara guru dengan siswa. Hal ini dapat dilakukan oleh guru dengan memberikan kode kelas kepada siswa, selanjutnya siswa dengan mudah untuk membuka pada halaman tugas. Setelah siswa membuka halaman tersebut akan tampak jenis tugas yang diberikan oleh guru. Guru dapat memberikan materi ajar, mengirimkan informasi yang berkaitan dengan pembelajaran, serta tugas-tugas untuk dikerjakan di kelasnya.

Tugas-tugas yang diberikan oleh guru dalam kegiatan pembelajaran pada aplikasi google classroom dapat juga dihubungkan dengan rinteraksi dan komunikasi dalam kelas untuk mengirimkan tugas melalui sarana e-mail. Dalam proses pembelajaran dengan aplikasi google classroom, guru dapat memperhatikan kegiatan yang dilakukan siswa dalam menyelesaikan tugasnya. Siswa yang telah menyelesaikan suatu tugas tertentu dan kemudian dikumpulkan akan terihat dengan cepat oleh guru. Demikian juga apabila tugas siswa yang telah diberi penilaiandan akan dikirimkan guru, maka siswa akan segera dapat mengetahuinya. 


\section{Metode Penelitian}

Metodologi penelitian yang dilakukan oleh penulis, dalam tindakannya dimulai sejak dikeluarkan kebijakan pemerintah pusat berkaitan dengan usaha pencegahan pandemic covid-19 dan kebijakan Pemerintah Provinsi DKI Jakarta sampai dengan masanormal kegiatan dilingkungan Dinas Pendidikan.

Penulis dalam penelitian ini menggunakan metode penelitian deskriptif, dimana penulis melakukan suatu pendeskripsian, menganalisis dan memferifikasi serta melakukan validasi atas gejala yang terjadi dalam objek penelitian. Metodologi penelitian deskriptif merupakan penelitian naratif berfungsi dalam design riset kualitatif atau kualitatif.

Penulis melakukan penelitian deskriptif dengan mendeskripsikan beberapa gejala, peristiwa, atau kejadian saat pembelajaran berlangsung dan kemudian didokumenkan hal-hal yang sifatnya urgenitas untuk diperhatikan dan bila itu menjadi masalah maka segera untuk dicarikan jalan keluarnya. Secara teori penelitian deskriptif memusatkan perhatian kepada pemecahan masalah pada saat penelitian dilaksanakan. Penulis mengupayakan suatu penelitian deskriptif yang lebih difokuskan pada pemecahan praktis dalam pembelajaran pada saat kondisi pandemic covid-19 atas layanan pendidikan. Penulis berupaya mendeskripsikan kejadiankejadian dari objek penelitian yang dijadikan vokus perhatiannya, selanjutnya penulis mengutarakan persoalan dalam penelitiannya sebagaimana adanya, sehingga karya tulisnya terdapat nilai manfaat dalam temuan penelitian deskriptif.

Dalam tulisan ini, penulis menganalisis tujuan penulisan dengan metode deskriptif agar lebih sistematis, fakta-fakta dilapangan lebih nampak, dan data akurat mengenai suatu gejala yang terjadi dengan sifat populasinya jelas. Hasil tulisan ini diharapkan dapat menjelaskan bagaimana perlakukan dan kebijakan yang berlaku pada saat pandemic covid-19 melanda dunia Pendidikan dan bagaimana solusi kebijakanyang diterapkan oleh pemangku pemerintahan dalam hal ini Sekolah, Dinas Pendidikan dan Kementrian Pendidikan dan Kebudayaan, serta mengetahui kecakapan hidup pesertadidik yang dihasilkan selama pandemi covid-19.

Penelitian dilaksanakan di SMA Negeri 67 Jakarta dengan alamat, Jl. Skadron, Halim Perdana Kusuma, Telp./ Fax. (021) 8090386 e-mail: info@ sman67-jkt.sch.id Website: http://www.sman67-jkt.sch.id, Jakarta Timur tempat penulis bertugas. Waktu penelitian dilakukan sejak kebijakan Dinas Pendidkan Provinsi DKI Jakarta memberlakukan work from home atau pembelajaran jarak jauh dan berakhir sampai dengan pelaksanaan Penilaian Akhir Sekolah. Atau dari 16 Maret 2020 sampaidengan 3 Juni 2020.

Populasi dari riset ini merupakan seluruh siswa kelas XI di SMA Negeri 67 Jakarta. Sedangkan sampelnya ditentukan dengan teknik purposive sampling. Data ini diambil dengan tujuan agar datanya lebih representatif. Teknik tersebut adalah teknik dalam menentukan sampel yang berfokus pada pertimbangan tertentu. Sampel penelitiannya adalah peserta didik kelas XI IPS SMA Negeri 67 Jakarta. 
Kecakapan Hidup dari Pembelajaran Pandemi Covid-19...

Pendapat Lofland dan Lofland seperti yang dikutip oleh Lexy. J. Moleong (2006:157) pada bukunya dengan judul Metodologi Penelitian Kualitatif, didalam buku tersebut menjelaskan bahwa sumber data yang utama dalam penelitian kualitatif adalah kalimat atau deskripsi dan perlakuan, selanjutnya data berikutnya merupakan tambahannya seperti dokumen dan seabagainya. Sehubungan dengan penelitian ini pada paparan yang telah diuraikan jelas datanya diklasifikaasikan ke dalam kalimatkalimat dan perlakuan, tertulis sumber datanya, gambar dan statistic.

Upaya yang dilakukan untuk mendapatkan dan mengumpulkan data, digunakan dengan teknik wawancara. Disamping itu dibantu oleh seseorang yang mengumpulkan sumber data dan disebut informan, informan adalah seseorang yang menjawab atau merespon setiap pertanyaan. Namun apabila dalam mengumpulkan data dengan teknik observasi, maka sumber datanya diperoleh dalam bentuk benda bergerak, demikian juga proses lainnya. Misalnya menggunakan dokumentasi, maka dokumen atau catatanlah yang menjadi sumber datanya.

Pada penelitian yang penulis lakukan, sumber data primernya berupa kalimat atau deskripsi yang didapat pada saat pelaksanaan pembelajaran selama pandemic covid-19 hingga pembatasan waktu pembelajaran sampai dengan pelaksanaan ujian akhir sekolah. Sedangkan sumber data sekundernya pada pelaksanaan penelitian berupa data seperangkat tujuan pembelajaran dan sarananya untuk mencapai tujuan, daftar nama siswa, surat edaran dan data Sekolah Menengah Atas Negeri 67 Jakarta.

Teknik pengumpulan data dilakukan selama proses pembelajaran berlangsung melalui Program Pembelajaran Jarak Jauh. (PJJ), dan pelaksanaan tes atau evaluasi pembelajaran dengan google form. Alat yang digunakan dalam pengumpulan data adalahbutir tes kognitif melaui google form dan e-mail, nomor urut absen dan nama e-mail. Soal-soal yang dipersiapkan untuk melaksanakan evaluai dalam bentuk word. Beserta pedoman pensekoran hasil test atau evaluasi. Prosedur pengambilan kesimpulan diawali dengan persiapan dari rencana pembelajaran jarak jauh menyesuaikan kurikulum 2013 tentang materi pembelajaran sejarah Indonesia. Langkah - langkah yang dilaksanakan dalam persiapan ini adalah merumuskan masalah, yang berkaitan dengan pembelajaran pada saat pandemic covid-19.

Selanjutnya peneliti mengkaji permasalahan dan daya dukung yang terdapat pada sekolah untuk dijadikan kajian dalam penelitian dan penulisan. Kegiatan selanjutnya adalah melakukan kajian pustaka, hal ini dilakukan agar mendapatkan keterangan dari para ahli yang lebih akurat terkait dengan masalah-masalah yang dijumpai dalampenelitian dan akan mendapatkan jalan keluar atau jawaban yang tepat mengenai masalahtersebut. Pada langkah perencanaan proses pembelajaran jarak jauh penulis merencanakan penyususunan program pembelajaran jarak jauh (RPP), dengan memperhatikan silabus, jadwal tatap muka atau jadwal pelajaran, dan model yang digunakan dalam proses pembelajaran jarak jauh. Sedangkan dalam tahap pelaksanaan penelitian diawali dengan proses pembelajaran disertai dengan kegiatan uji kompetensi untuk mengukur kemampuan peserta didik sebagai penilaian dengan menggunakan google form dan emailpeserta didik yang dijadikan sebagai data primer. 


\section{Pengumpulan Data}

Setelah selesai melaksanakan tes atau uji kompetensi sebagai bentuk ulangan harian, maka masing - masing siswa diberi kesempatan waktu untuk dapat menyelesaikan tugas hariannya kemudian disubmit dan dikirimkan melaui e-mail untuk diproses selanjutnya. Pada saat mengolah data dan selanjutnya akan dijadikan sebagai laporan, penulismelakukan proses olah data dan analisis hasil data penelitian kemudian menyususn kesimpulannya, dan selanjutnya membuat laporan hasil penelitian. Dengan langkah- langkah: menyusun jadwal penelitian; menyususn setting penelitian; menyusun item soal ulangan harian; memilih materi esensial dan hal-hal yang akan dikembangkan terkait pelaporan pembelajaran; menyusun lembar kerja peserta didik; menyusun dan menentukan kriteria atau patokan penilaian hasil pekerjaan peserta didik; memberikan tanggapan bagi peserta didik yang merespon atas persoalan materi ajar yang belum difahami berkaitan dengan teknik pembelajaran maupun materi pembelajaran; dan mendokumentasikan semua aktivitas kegiatan pembelajaran. Desain Penelitian yang dirancang penulis berpedoman pada pendapat Sanapiah dan Punaji, sebagai berikut:

Berdasarkan tujuan dan metode penelitian, maka desain penelitian yang dipakai adalah penelitian deskriptif. Suatu bentuk penelitian penelitian dimana penulis melakukan penelitian dengan tujuan untuk menggambarkan kejadian-kejadian atau fenomena pada saat penelitian, baik natural maupun fenomena yang dibuat oleh manusia".

Penelitian deskriptif merupakan suatu penelitian dengan tujuan untuk mendeskripsikan atau menguraikan suatu kondisi, kejadian, objek penelitian atau orang, ataupun berbagai hal yang berkaitan dengan variable atau besasan angka yang dapat dijelaskan melalui kalimat atau kata-kata juga dapat dengan angka-angka. (Punaji Setyosari: 2010: 194)

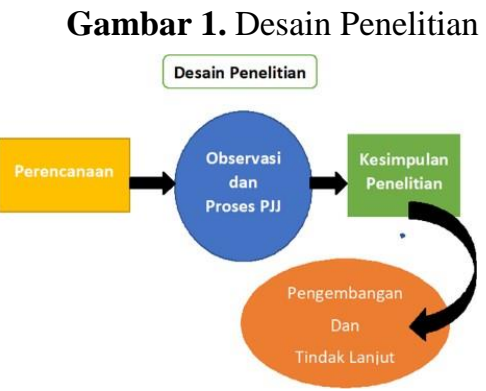

Dalam pengumpulan data digunakan teknik sebagai berikut adalah semua aktifitas dalam kegiatan pembelajaran, studi Pustaka dan dokumentasi yang berhubungan dengan kegiatan pembelajran jarak jauh. Teknik analisis data dan pengambilan kesimpulan dengan cara menganalisa data dari data kualitatif yang penulis paparkan pada tulisan ini dan dengan cara yang lazim dipakai dantelah dideain secara sederhana dengan suatu metode yang oleh para ahli sudah diterapkanpada riset sosial oleh Alan Bryman. Lalu langkah selanjutnya adalah bagaimana penulis paparkan dengan singkat dan disertai data yang diperolah agar memudahkan dalam memahami isi tulisan ini. 
Kecakapan Hidup dari Pembelajaran Pandemi Covid-19...

Secara umum kita ketahui bahwa ada setidaknya dua pendekatan untuk analisis data kualitatif, yang pertama analisis induksi dan grounded. Jenis atau bentuk grounded kadangkala diidentikkan dengan deduktif namun pada hakikatnya tidak demikian halnya. Dalam karya ini penulis mengambil langkah seperti pendapat Alan Bryman, dengan alasan karena cukup memudahkan untuk difahami dalam membedakan analisis kualitatifke dalam dua pendekatan tersebut.

Dengan menggunakan pendekatan analisis induksi, maka penulis mengambil kesimpulan diawali dari hipotesis yang telah ditulis sebelumnya oleh penulis pada saat awal sebelum terjun dilapangan. Hal ini dilakukan karena pelaksanannya sangat mirip dengan pendekatan kuantitatif murni, akan tetapi lebih bersifat terbuka saat berada dilapangan. Setelah dilapangan, dan penulis melakukan proses kegiatan pembelajaran maka secara bersamaan dengan melakukan penelitian diharapkan data yang diperoleh dapat mengonfirmasikan hasil hipotesis untuk dijadikan kesimpulan.

Adanya kebijakan pemerintah terkait permasalahan pandemic covid-19 dipastikan dapat mempengaruhi diberbagai bidang kehidupan, seperti halnya bidang ekonomi, bidang Kesehatan bidang pendidikan, dan kehidupan sosial kemasyarakatan.Disektor pendidikan, salah satunya adalah adanya model pembelajaran dari tatap muka berubah menjadi pembelajaran jarak jauh. Model belajar jarak jauh dapat dipaastikan mempunyaidampak baik positif maupun negatif, sisi positif adanya belajar jarak jauh adalah : pesertadidik dan guru tidak perlu pergi ke sekolah di masa pandemi covid-19, selanjutnya proses belajar mengajar lebih leluasa hal ini karena dapat dilakukan pada saat berada didalam rumah atau ditempat lain yang memungkinkan untuk belajar..

\section{Kecakapan Hidup}

Menurut aturan yang telah diundangkan oleh pemerintah Republik Indonesia No. 20 tahun 2003 mengenai Sisdiknas, pada penjelasan ps. 26 ayat 3 disana dijelaskan : pendidikan kecakapan hidup (life skill) merupakan pendidikan yang dapat memberi kecakapan perseorangan, kecakapan sosial, kecakapan daya fikir yang tinggi berkaitan dengan ilmu pengetahuan, budi pekerti dan daya akal serta kecakapan vokasional dalam usaha kemandirian maupun bekerja.

Pandemic covid-19 memberi pelajaran tersendiri terhadap semua manusia dalam prilaku hidupnya. Seperti menjaga kesehatan phisik dengan cara cuci tangan, menggunakan masker, pola hidup bersih, semua ini merupakan kecakapan hidup, yang perlu dipertahankan dan dikembangkan. Sedangkan menjaga kesehatan psikologis seperti ketenangan batin, cara berfikir, konsentrasi serta rasa bersyukur merupakan perasaan yang harus dijaga agar imunitas pada diri seseorang selalu optimis.

Kecakapan hidup yang lain adalah pemakaian alat komunikasi seperti gawai ataugadget dan laptop, dengan mengoperasikan kedua alat tersebut, para pelajar dapat menambah ilmu pengetahuan dan ketrampilannya pada saat mengoperasikan dan juga mengetahui fitur-fitur yang terdapat dalam progaramnya. Kemampuan literasi dan kerjasama kelompok dalam diskusi untuk menyelesaikan tugas dalam setiap mata 
Sarwiyoto

pelajaran yang diberikan guru adalah suatu sikap yang perlu dibiasakan sehingga menjadi karakter bagi setiap peserta didik.

Dari survei yang penulis lakukan terhadap peserta didik berkaitan dengan kesehatan dan kehadiran dalam pembelajaran jarak jauh selama pandemi covid-19 terhadap 144 orang, diperoleh data yang menunjukkan bahwa peserta didik dalam keadaan sehat dan selalu hadir dalam pembelajaran.

Gambar 2. Angket PJJ berkaitan dengan Kesehatan

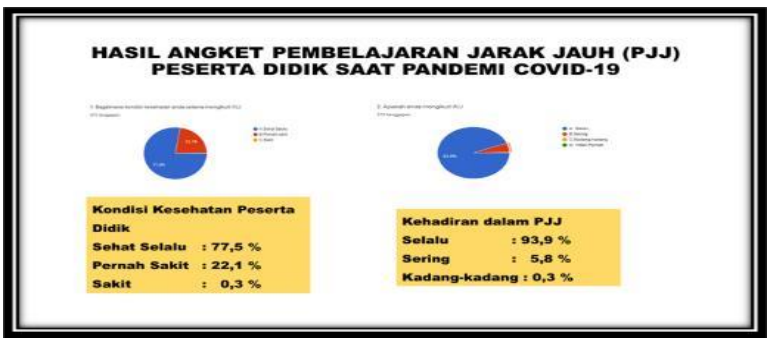

Sedangkan angket yang menanyakan tentang media daring yang sering digunakan oleh guru dengan pilihan seperti Google clasroom, Whats Aps, Google meet dan Zoom meet, diperolah data bahwa sebagian besar peserta didik menjawab media google classroom menempati urutan pertama dengan alasan lebih mudah diterima peserta didik.

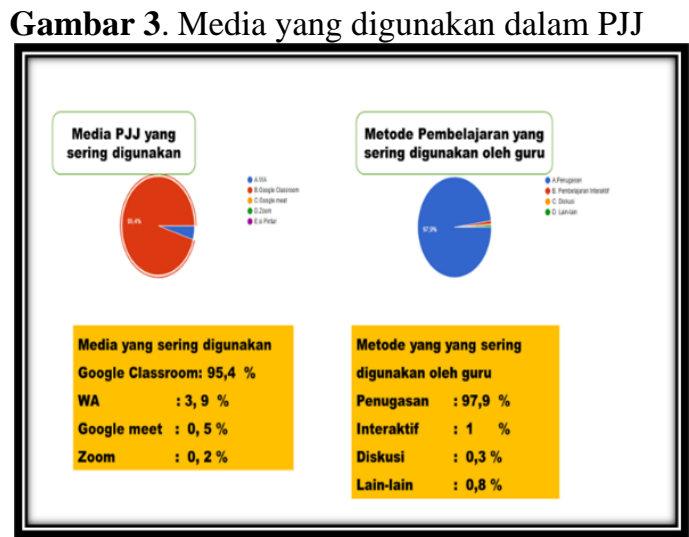

Dalam hal kemampuan dan efektifitas pembelajaran jarak jauh para peserta didik yang disurvey menjawab dirinya merasa mampu dalam mengerjakan tugas sebesar: 59,5\%, cukup mampu: 32,6\%. Sedangkan tingkat keefektifan PJJ selama pandemi covid-19, jawaban peserta didik adalah, sangat efektif: $2,4 \%$, cukup efektif: $37,9 \%$, kurang efektif: $48,1 \%$, dan tidak efektif: $11,6 \%$.

Gambar 4. Kemampuan dan efektifitas PJJ

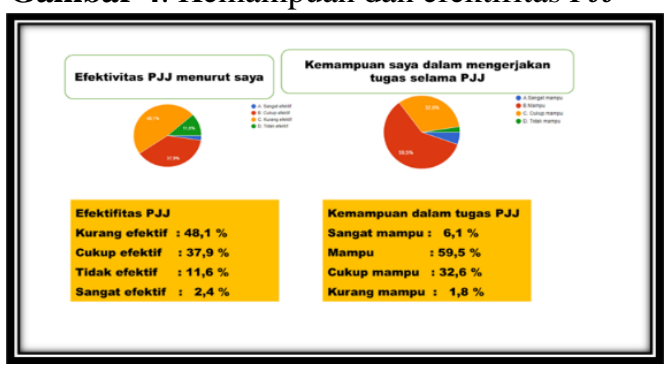

Vol. 3 No. 2 (2021) 
Kecakapan Hidup dari Pembelajaran Pandemi Covid-19...

\section{KESIMPULAN}

Pandemi covid-19 tidak saja membuat darurat kesehatan. Namun banyak juga negara yang mengalami krisis ekonomi karenanya. Oleh sebab itu para pakar kesehatan menghimbau dalam upaya mencegah pandemi ini dengan istilah 'social distancing' dan 'lockdown', sedangkan upaya menangani krisis ekonomi oleh lembaga keuangan dunia mengarahkan agar negara-negara yang mengalami kesulitan ekonomi untuk dibantu.

Krisis kesehatan dan krisis ekonomi merupakan buah simalakama dalam penanganannya, mengingat keduanya sangat penting dan saling berkiatan. Namun keduanya dapat dianalogikan jika kita sedang mengendarai sebuah mobil dan tiba-tiba mobil tersebut mati mendadak sementara kita tidak mengetahui apa-apa tentang mobil, jalan keluar terbaiknya adalah dengan memanggil ahlinya Dibidang pendidikan yang memproses sumber daya manusia sebagai generasi yang akan mengisi bangsa ini dikemudian hari, itupun wajib mendapatkan layanan yang memadai saat pandemi covid 19.

Melalui regulasi yang digulirkan kementrian pendidikan dan jajarannya berupaya agar pendidikan tetap berjalan sesuai aturan. Pada unit pelaksana, seperti disekolah- sekolah pembelajaran tetap berjalan dengan sistem daring. Media daring yang digunakandari hasil survei menunjukkan bahwa mayoritas guru memakai google classroom, hal ini dikarenakan media tersebut sangat aman untuk pembelajaran, dan banyak memiliki aplikasi campuran yang dapat difungsikan sebagai sarana belajar.

Dampak positif pandemi covid-19 dalam proses pembelajaran adalah lahirnya kecakapan hidup seperti mempraktikkan pola hidup bersih dan sehat, menambah pengetahuan dibidang informasi dan telekomunikasi serta pola-pola hidup yang tidak dipraktikkan sebelum adanya pandemi covid-19. Sebagai akhir tulisan ini, penulis menyarankan kepada pemerintah untuk waspada dan belajar dari pandemi covid-19. Kelebihan dan kekurangan dalam pencegahan dan penanganan pandemi tersebut menjadipelajaran dimasa datang.

Tidak semua peserta didik dapat mengakses internet sebagai sarana program pembelajaran jarak jauh, oleh sebab itu jaringan internet untuk selalu dipantau sebagai upaya perbaikan kedepan. Tidak saja masalah jaringan internet namun peserta didik yang bernasib kurang beruntung, itupun menjadi perhatian agar mereka dapat mengakses internet sebagai sarana pembelajaran agar tidak ketinggalan dengan daerah lain. Guru sebagai ujung tombak dalam pendidikan hendaknya selalu membekali diri dalam rangka meningkatkan dan mengembangkan kompetensinya dalam rangka melayani para siswa pada saat proses belajar mengajar serta mampu menyesuaikan kehidupan pada abad revolusi industri 4.0.

\section{DAFTAR PUSTAKA}

Abdul,Barir Hakim. (2016). Jurnal I-Statement. Efektivitas Penggunaan ELearningMoodle,Google Classroom Dan Edmodo, Vol.02 No 1 h.2.

Anas Sudijono. 2009. Pengantar Evaluasi pendidikan. Jakarta. PT. Raja Grafindo 
Persada.

Arikunto, S. (2014). Prosedur Penelitian. Cetakan Ke-15. Jakarta: PT. Rineka Cipta.

COVID-19, Tantangan Besar bagi Semua Tenaga Kesehatan, diunduh dari https://duta.co/covid-19-tantangan-besar-bagi-semua-tenaga-kesehatan, pada 14

April 2020

Darmawan, Deni. (2014). Pengembangan E-Learning Teori dan Desain, Jakarta, PT Remaja.

Daryanto. (2016). Media Pembelajaran. Cetakam Ke-4. Bandung: PT. Sarana

Dimyati dan Mudjiono. (2013). Belajar dan Pembelajaran. Cetakan kelima. Rineka Cipta.

Jakarta.

Erlina Burhan, (2019) https://luk.staff.ugm.ac.id/artikel/virus/ErlinaBurhan-COVID19.pdf

Gora, Winastawan. (2005). Penggunaan Tekologi Informasi vs Integrasi Teknologi Infomasi dalam pembelajaran. Tersedia di: http://edupartner.org/?p=95.

Hamalik, Oemar. (2012). Teknologi dalam Pendidikan, Bandung: Yayasan Partisipasi Pembangunan Indonesia.

Indrawan, R, Yuniawati, P. (2016). Metodologi Penelitian. Edisi Revisi. Cetakan Kedua.

Bandung: PT. Refika Aditama.

JURNAL PENDIDIKAN: Riset dan Konseptual, dalam: www.journal.unublitar.ac.id/jp Vol. 3 No. 2, April 2019 E-ISSN: 2598-2877 P-ISSN: 2598-5175

Kamus Besar Bahasa Indonesia, Edisi Keempat, 2008, Gramedia Pustaka Utama, Jakarta.http://kbbi.web.id/paham

Kemendikbud. (2013). Permendikbud No. 109 tentang Penyelenggaraan Pendidikan Jarak Jauh pada Pendidikan Tinggi. Jakarta: Kementrian Pendidikan dan Kebudayaan.

Lexy. J. Moleong, (2006). Metodologi Penelitian Kualitatif, Bandung: PT Remaja Rosdakarya.

Munir. (2010). Pembelajaran Jarak Jauh. Bandung: Alfabeta.

Punaji, Setyosari. 2010. Metode Penelitian Pendidikan dan Pengembangan. Jakarta Kencana.

R Poppy Yaniawati. (2010). E-Learning dan Alternatif Pembelajaran Kontemporer.

Bandung: Arfino Raya. 
Kecakapan Hidup dari Pembelajaran Pandemi Covid-19...

Sudjana, Nana, dan Ibrahim, 1989, Penelitian Kualitatif dan Kuantitatif, Bandung: SinarBaru

Sanapiah Faisal. 2008. Format-format Penelitian Sosial. Jakarta: Rajawali Pers.

Sanjaya, Wina. (2013). Strategi Pembelajaran Berorientasi Standar Proses

Pendidikan.

Jakarta : Prenada Media Group

Sugiyono. (2012). Metode Penelitian Kuantitatif Kualitatif Dan R\&D. Bandung: Alfabeta.

Ula Nisa El Fauziah, dkk., (2019). Jurnal Abdimas IKIP Siliwangi. Penerapan Google Classroom dalam Pembelajaran Bahasa Inggris, Volume 02 Nomor 02, Juli 2019

UU RI No.20 Th.2003, 2006: UU SISDIKNAS, Jakarta: Asa Mandiri. 